\title{
The laboratory control of thrombolytic therapy
}

\author{
CHRISTINE HAWKEY AND MARGARET HOWELL \\ From the Department of Haematology, St. George's Hospital and Medical School, London
}

SYNOPSIS Methods are described by which thrombolytic therapy with local and systemic infusion of streptokinase can be initiated and controlled.

Thrombolytic therapy with continuous infusion of streptokinase has been shown to be an effective form of treatment in certain thrombo-embolic conditions. This paper presents details of methods which have proved satisfactory for laboratory control of the treatment of 24 patients. Clinical results are reported elsewhere (Hawkey and Howell, 1964).

Streptokinase can be given either systemically by an intravenous drip in order to induce a high level of activator throughout the circulation, or by local infusion into an occluded artery so that relatively large amounts of activator can be delivered close to the thrombus with minimal activation of the plasminogen elsewhere. Whichever route is used, intravascular thrombolysis ultimately depends on the maintenance of a high local concentration of activator in order to activate the plasminogen within the thrombus (Alkjaersig, Fletcher, and Sherry, 1959a). The presence of activator in the general circulation does, however, result in the production of plasmin and, although this is to some extent inactivated by circulating antiplasmins, some plasmin remains capable of degrading certain plasma clotting factors. During infusions of activator this systemic effect may impair blood coagulation: tests should be carried out at frequent intervals to assess the concentration of activator and to screen for the development of any defect of haemostasis.

Streptokinase is antigenic and human blood contains antibodies, present as a result of incidental streptococcal infections. The anti-streptokinase antibody level varies considerably amongst individuals and therefore it is necessary to carry out a titration before the infusion is begun in order to calculate the neutralizing dose for a given case. In systemic therapy a loading dose of streptokinase large enough to overcome the antibodies present must be given before the required effect will be apparent in the general circulation. When streptokinase is given locally, however, the antibodies will

Received for publication 12 February 1964. neutralize it in the general circulation, thus limiting systemic activation; in this situation an initial knowledge of the antibody level permits estimation of the amount of streptokinase which can be given without the accumulation of free streptokinase in the circulating blood.

Although not essential for the actual control of infusions of streptokinase, assays of plasminogen, fibrinogen, and other clotting factors have been carried out in order to confirm the interpretations of the screening tests and to gain information about the effects of streptokinase in vivo.

\section{MATERIALS}

STREPTOKINASE FOR INFUSION Kabikinase (Kabi Pharmaceuticals Ltd., London), a highly purified form of streptokinase, has been used throughout for infusion. Pilot samples are available for use in the anti-streptokinase antibody titration.

STORAGE TUBES FOR E.A.C.A. Volumes, each of $0.1 \mathrm{ml}$, of $10 \%$ epsilon-amino-caproic acid (E.A.C.A.) are dispensed in polystyrene tubes and dried in a hot air oven at $60^{\circ} \mathrm{C}$. One millilitre of plasma is stored in each tube so that the final concentration of E.A.C.A. is $10 \mathrm{mg} . / \mathrm{ml}$. plasma (Nilsson and Olow, 1962a).

THROMBIN Thrombin reagent (Leo Pharmaceutical Products, London) is recommended for use in fibrinolytic tests as it is free from contamination with significant amounts of components of the fibrinolytic system (Hawkey and Stafford, 1964). A stock solution containing 500 N.I.H. units $/ \mathrm{ml}$. physiological saline is stored in aliquots at $-35^{\circ} \mathrm{C}$. Solutions of the required strength are prepared from this by dilution with saline. Solutions of 50 units $/ \mathrm{ml}$. are stable at $4^{\circ} \mathrm{C}$. for up to four hours but weaker solutions should be freshly prepared after one hour.

HUMAN SERUM EUGLOBULIN AS A SOURCE OF PLASMINOGEN This is prepared by the method of Howell (1963) and standardized as described by Hawkey and Stafford (1964). Although plasminogen in this form shows no tendency 
to autoactivate, the absence of plasmin is confirmed by including $0.1 \mathrm{ml}$. of the serum euglobulin in a euglobulin lysis test on normal plasma. A control is set up using buffer in place of the serum euglobulin. If similar lysis times are recorded in the test and control plasmin is not present.

ACIDIFIED DISTILLED WATER Glacial acetic acid, $0 \cdot 1 \mathrm{ml}$, in 1 litre glass-distilled water is stored at $4^{\circ} \mathrm{C}$. in an automatic pipette (Jencons Ltd.) adjusted to deliver $9 \mathrm{ml}$. aliquots.

PHOSPHATE BUFFER $p$ H $7 \cdot 4$ (FEARNLEY, BALMFORTH, AND FEARNLEY, 1957) $\mathrm{Na}_{2} \mathrm{HPO}_{4}, 9.47 \mathrm{~g}$., is dissolved in 1 litre distilled water. To this is added $3.02 \mathrm{~g}$. $\mathrm{KH}_{2} \mathrm{PO}_{4}$ dissolved in $250 \mathrm{ml}$. distilled water.

SAline/E.A.C.A. E.A.C.A., 0.5 g., is dissolved in $500 \mathrm{ml}$. physiological saline. This reagent is prepared on the day of use.

TYROSINE STANDARD FOR FIBRINOGEN ASSAY DL-tyrosine (British Drug Houses), $200 \mathrm{mg}$., is dissolved in $950 \mathrm{ml}$. $0 \cdot 1 \mathrm{~N} \mathrm{HCl}$. To this is added $50 \mathrm{ml}$. isopropanol. This solution is stable indefinitely at room temperature.

FOLIN CIOCALTEAU REAGENT (BRITISH DRUG HOUSES)

SORENSEN'S PHOSPHATE BUFFER $\mathrm{Na}_{2} \mathrm{HPO}_{4}, 9.526$ g., 0.907 g. $\mathrm{KH}_{2} \mathrm{PO}_{4}$, and 4.5 g. $\mathrm{NaCl}$ are dissolved in 1 litre distilled water and the $p \mathrm{H}$ adjusted to $7 \cdot 5$.

FIVE PER CENT CASEIN SOLUTION Hammarsten casein (British Drug Houses), $25 \mathrm{~g}$., is dissolved in $500 \mathrm{ml}$. Sorensen's buffer. This solution is boiled for 20 minutes, filtered while hot, and the $p \mathrm{H}$ re-adjusted to $7 \cdot 6$. It is stored in aliquots at $-35^{\circ} \mathrm{C}$. (Biggs and Macfarlane, 1962).

STREPTOKINASE FOR PLASMINOGEN ASSAY An impure form of streptokinase (Streptokinase-Streptodornase Varidase, Lederle Laboratories) is used to convert plasminogen to plasmin for caseinolytic assay. A stock solution containing 10,000 units $/ \mathrm{ml}$. saline is stored at $-35^{\circ} \mathrm{C}$.; the required solution containing 2,000 units $/ \mathrm{ml}$. is prepared from this by dilution with saline.

TYROSINE STANDARD FOR PLASMINOGEN ASSAY DLtyrosine (B.D.H.), $36 \mathrm{mg}$., is dissolved in $950 \mathrm{ml} .0 \cdot 1$ $\mathrm{N} \mathrm{HCl}$. To this is added $50 \mathrm{ml}$. isopropanol.

POLYTHENE PASTEUR PIPETTES Opaque polythene tubing (C. E. Payne, London) is drawn out into pasteur pipettes after gently warming above a bunsen burner flame.

FACTOR X SUBSTRATE PlaSma (Diagnostic Reagents, Thame, Oxon.)

\section{METHODS}

COLLECTION OF BLOOD An initial sample of blood is collected as soon as possible. In systemic therapy the second sample is taken as soon as the loading dose has $\stackrel{\overrightarrow{7}}{\overrightarrow{0}}$ been given and the third sample one hour later. Thereafter tests are best carried out at four-hourly intervals. During local infusion the second sample is collected four hours after the beginning of the infusion and further samples obtained as indicated. Great care should be $\overline{\bar{\omega}}$ taken to keep the samples cool at all times to prevent $\frac{\vec{\nabla}}{\vec{D}}$ proteolytic activity and to reduce the development of the $\varrho$ inhibitor of plasminogen activation (anti-activator) which is produced in shed blood (Flute, 1960).

Venous blood is obtained with minimal stasis using $\overrightarrow{0}$ chilled apparatus. For the initial sample it is convenient $\overrightarrow{\vec{\omega}}$ to use a S.W.G. 18 needle attached to a short length of $\widetilde{\omega}$ polythene tubing; in this way the large volume of blood required can be obtained without changing syringes. ? For other samples a chilled syringe is used (the needle is $\vec{V}$ not cooled). Blood for the anti-streptokinase antibody $\omega$ titration is mixed in a pre-cooled polystyrene container $\mathrm{N}_{\infty}$ with $0.1 \mathrm{ml} .10 \%$ E.D.T.A. per $10 \mathrm{ml}$. blood. Blood for fibrinolytic and clotting tests is placed in a similar $\frac{\mathrm{O}}{\mathrm{O}}$ container with 1 part $3.8 \%$ trisodium citrate to 9 parts $\rightarrow$ of blood. The E.D.T.A. and citrated samples are centrifuged immediately at $4^{\circ} \mathrm{C}$. for 10 minutes at $1,688 \mathrm{~g}$ (3,000 r.p.m.). Euglobulin lysis tests, coagulation $\overrightarrow{0}$ screening tests, and, on the initial sample, the anti- o streptokinase antibody titration, are set up immediately. Plasma for the assay of fibrinogen and clotting factors is stored at $-35^{\circ} \mathrm{C}$. in tubes containing E.A.C.A. Plasma for plasminogen estimation is mixed with $\mathrm{N} / 6 \mathrm{HCl}$ to inactivate antiplasmins (Alkjaersig, Fletcher, and Sherry, 윰 $1959 \mathrm{~b})$ and after neutralization of the acid the samples $\frac{O}{(1)}$ are stored at $-35^{\circ} \mathrm{C}$.

Blood for grouping and complete blood count, $\overrightarrow{\overrightarrow{0}}$ including platelet estimation, is collected with the first 3 sample.

ESTIMATION OF THE INITIAL DOSE OF STREPTOKINASE It is important to begin thrombolytic therapy as soon as? possible, not only to limit the time of ischaemia of the affected part but also because clots become resistant to lysis with age (Johnson and McCarty, 1959). A simple, $\frac{\varrho}{2}$ rapid method of determining the loading dose is therefore required and the following modification of the method of $\mathrm{O}$ Tillett, Johnson, and McCarty (1955) has been found satisfactory. The E.D.T.A. is used as anticoagulant $\frac{D}{2}$ together with a strict cold handling technique in order to prevent the development of anti-activator (Flute, 1960) $\mathrm{N}$ which could influence the result of this test.

Streptokinase of the type to be used for infusion is $N$ diluted with physiological saline to give a solution $\omega$ containing 5,000 units $/ \mathrm{ml}$. All streptokinase dilutions are made up immediately before use and kept in an ice bath. A series of dilutions is prepared as shown in Table $1 . \frac{\mathrm{C}}{\bar{D}}$ Of each dilution, $0.05 \mathrm{ml}$. is pipetted into a duplicate $\$$ series of tubes in an ice bath and, using a graduated polythene pipette, $0.5 \mathrm{ml}$. chilled E.D.T.A. plasma is $\frac{T}{O}$ added to each tube, beginning with the saline control $\frac{\vec{D}}{\mathbb{D}}$ and the lowest concentration of streptokinase. Immedi- $\frac{\rho}{\square}$ ately, $0 \cdot 1 \mathrm{ml}$. of thrombin ( 50 units $/ \mathrm{ml}$.) is added to $\stackrel{\mathbb{Q}}{\varrho}$ each tube, the tubes shaken and transferred to a water $\bar{\sigma}$ bath at $37^{\circ} \mathrm{C}$. A stop watch is started as thrombin is added to the first tube. The tubes are examined after one $ᄋ$ 
TABLE I

PREPARATION OF STREPTOKINASE DILUTIONS FOR THE ANTIBODY TITRATION

\begin{tabular}{llc}
$\begin{array}{l}\text { Streptokinase } \\
(5,000 \text { units } / \text { ml. })\end{array}$ & Saline & $\begin{array}{l}\text { Streptokinase } \\
\text { (units/ml. Plasma) }\end{array}$ \\
\hline $0 \cdot 15 \mathrm{ml}$. & $0 \cdot 1 \mathrm{ml}$. & 300 \\
$0 \cdot 1$ & $0 \cdot 15$ & 200 \\
$0 \cdot 1$ & $0 \cdot 4$ & 100 \\
$0 \cdot 1$ & $0 \cdot 9$ & 50 \\
$0 \cdot 1$ & $2 \cdot 4$ & 20 \\
$0 \cdot 1$ of 50 units $/ \mathrm{ml}$. & 0.9 & 5 \\
0 & Neat saline & 0
\end{tabular}

minute to confirm that clotting has taken place and after 20 minutes for lysis.

The initial dose of streptokinase for systemic activation is based on the smallest number of units of streptokinase which will bring about complete lysis in 20 minutes. This number is multiplied by the patient's plasma volume estimated on a body weight basis. The required number of units is dissolved in physiological saline or $5 \%$ dextrose and infused over a period of 30 minutes, to be followed immediately by a sustaining dose which is usually related to the size of the initial dose (Fletcher, Alkjaersig, and Sherry, 1959a).

ASSESSMENT OF ACTIVATOR ACTIVITY A euglobulin lysis test adapted from the method of Buckell (1958) is used. Because plasminogen may be depleted during infusion of streptokinase additional tests are set up to which plasminogen in the form of human serum euglobulin is added.

Chilled citrated plasma, $0.5 \mathrm{ml}$., is added to $9 \mathrm{ml}$. ice-cold distilled water acidified with acetic acid to give a final $p \mathrm{H}$ of 5.3. After mixing, the euglobulin precipitate is obtained by centrifuging immediately at $4^{\circ} \mathrm{C}$. for five minutes at 1,688 $g$ (3,000 r.p.m.). The supernatant is discarded and the precipitate re-dissolved in $0.5 \mathrm{ml}$. phosphate buffer. Then $0.4 \mathrm{ml}$. of the re-dissolved precipitate is clotted in a glass tube at $37^{\circ} \mathrm{C}$. by adding $0 \cdot 1 \mathrm{ml}$. thrombin ( 50 units $/ \mathrm{ml}$.). At the same time a second test is set up in which $0.1 \mathrm{ml}$. of human serum euglobulin is added to $0.4 \mathrm{ml}$. of re-dissolved euglobulin precipitate before clotting. A stop watch is started as the thrombin is added and the tubes examined at intervals for lysis. The time taken for complete lysis of the clot at $37^{\circ} \mathrm{C}$. is the euglobulin lysis time.

The euglobulin lysis time is normally longer than 90 minutes; a marked shortening of this time during local infusion indicates that free streptokinase is present in the circulation and the dose should be reduced. During sy stemic therapy the loading dose of streptokinase should shorten the lysis time to less than 20 minutes and the drip rate is increased, if necessary, in order to maintain this level of activity throughout the infusion. If the circulating plasminogen is grossly depleted, the test with added plasminogen will lyse more rapidly than the one without and gives a measure of the activator level. Failure of the euglobulins to clot on addition of thrombin indicates a level of activator high enough to result in marked or complete fibrinogenolysis, either in vivo or during the setting up of the test. In these circumstances the infusion rate should be reduced.
COAGULATION SCREENING TESTS These are the estimation of the one-stage prothrombin time and of the thrombin times.

One-stage prothrombin time This is carried out on citrated plasma by the method of Quick (1957) modified by the use of a saline extract of human brain as a source of thromboplastin.

During systemic fibrinolytic states the prothrombin time becomes prolonged due to the breakdown of plasma clotting factors and the anticoagulant effects of fibrinogen breakdown products. Assays of factors V, VII, and X on plasma samples collected during infusion confirm that no gross reduction of these factors occurs while the prothrombin activity is greater than $25 \%$.

Thrombin times Thrombin solution, $0.2 \mathrm{ml}$, is added to $0.2 \mathrm{ml}$. of citrated plasma at $37^{\circ} \mathrm{C}$. and the clotting time recorded.

During sustained fibrinolytic activity in vivo the thrombin clotting time is influenced by two factors; first the reduction in circulating fibrinogen due to fibrinogenolysis by free plasmin. and secondly, by the 'antithrombin' effect of accumulating fibrinogen breakdown products (Niewiarowski and Kowalski, 1958; Fletcher, et al., 1959b). In order to assess each of these effects, tests are carried out using two different strengths of thrombin, namely, a solution containing 50 N.I.H. units $/ \mathrm{ml}$. to give an indication of the fibrinogen level and a weaker solution containing 5 units $/ \mathrm{ml}$. which is sensitive to the presence of antithrombin activity. The normal range for these tests is:

Thrombin, 50 units $/ \mathrm{ml} . \ldots \ldots \ldots \ldots \ldots \ldots 5-8$ seconds

An increase in the strong thrombin time of more than five seconds indicates a reduction in the fibrinogen level to less than $100 \mathrm{mg}$. $/ 100 \mathrm{ml}$. A lengthening of the weak thrombin time to 100 seconds or more is usually accompanied by a deterioration in the quality of the clot probably due to interference of fibrin polymerization by products of fibrinogen breakdown. The weak thrombin test often remains prolonged after the fibrinogen level has returned to normal, indicating that the clearance rate of fibrinogen breakdown products is slow; this fact should be borne in mind if heparin is to be used directly after an infusion of streptokinase.

FIBRINOGEN ESTIMATION Fibrinogen should be measured by its ability to clot, as the presence of fibrinogen breakdown products may affect the results of immunological and precipitation methods. A modification of the method of Ratnoff and Menzie (1951) has been used in the present study.

Citrated plasma is mixed with E.A.C.A. as soon as possible after collection and stored at $-35^{\circ} \mathrm{C}$. For the test, plasma is thawed at $37^{\circ} \mathrm{C}$., and $0.2 \mathrm{ml}$. plasma is mixed with $1 \mathrm{ml}$. of saline/E.A.C.A. and approximately $0.5 \mathrm{ml}$. of crushed, acid-cleaned, pyrex glass and clotteo with $0.05 \mathrm{ml}$. thrombin (500 units/ml.). After 30 minutes at room temperature the tubes are shaken vigorously to break up the clots and collect the fibrin on the crushed glass. The mixture of glass and fibrin is washed twice in 
saline/E.A.C.A. Then $4 \mathrm{ml}$. of $1 \% \mathrm{NaOH}$ is added and the tubes placed in a boiling bath for 10 minutes to hydrolyse the fibrin. When cool, $1.2 \mathrm{ml}$. of $20 \% \mathrm{Na}_{2} \mathrm{CO}_{3}$ and $0.4 \mathrm{ml}$. Folin Ciocalteau reagent is added and after 10 minutes, during which time the colour develops, a 1 in $\mathbf{4}$ dilution of the supernatant is made in distilled water. Colour is read in a Unicam SP1500 spectrophotometer at a wavelength of $650 \mathrm{~m} \mu$ against a thrombin blank set up in the same way as the tests but with no plasma.

A calibration curve is prepared from a standard tyrosine solution; this is used to convert spectrophotometer readings to milligrams tyrosine, when mg. tyrosine $\times 16.4=\mathrm{mg}$. fibrinogen $/ 100 \mathrm{ml}$. plasma. Correction must be made for dilution of the original plasma by citrate.

PLASMINOGEN ESTIMATION This is carried out by the caseinolytic assay described by Remmert and Cohen (1949) as modified by Alkjaersig et al. (1959a).

The tests are set up in duplicate. Chilled citrated plasma, $0.5 \mathrm{ml}$, is added to $0.5 \mathrm{ml}$. N/6 $\mathrm{HCl}$ and after 15 minutes at room temperature the acid is neutralized by the addition of $0.5 \mathrm{ml}$. N/6 NaOH. The samples can be stored at $-35^{\circ} \mathrm{C}$. at this stage.

For the test, the samples are thawed and the following reagents added:

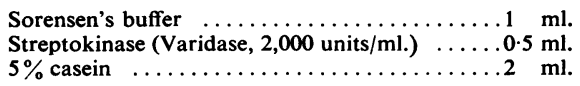

After mixing, the tubes are placed immediately in a water bath at $37^{\circ} \mathrm{C}$. and after two and 62 minutes, $1 \mathrm{ml}$. sub-samples are transferred to tubes containing $1 \mathrm{ml}$. of $10 \%$ trichloracetic acid (T.C.A.). These tubes are shaken vigorously and centrifuged at 3,000 r.p.m. $(1,688 \mathrm{~g})$ for 10 minutes.

Trichloracetic acid soluble peptides in the supernatant are measured using Folin Ciocalteau reagent and $0.5 \mathrm{ml}$. of the supernatant is added to $2.5 \mathrm{ml} .0 .5 \mathrm{~N} \mathrm{NaOH}$. To this is added $0.75 \mathrm{ml} .5 \%$ T.C.A. and $0.75 \mathrm{ml}$. Folin Ciocalteau reagent diluted with an equal amount of distilled water. The 62-minute sample is read against the two-minute blank in a Unicam SP1500 at a wavelength of $650 \mathrm{~m} \mu$.

A calibration curve is prepared using standard tyrosine solution. One unit of plasminogen releases $180 \mu \mathrm{g}$. of tyrosine from casein under the conditions of the test (Alkjaersig et al., 1959b). Correction must be made for dilution of the original plasma by citrate.

FACTOR V ASSAY By the method of Stefanini (1951) modified by Wolf (1953).

FACTOR VII ASSAY By the method of Dische and Benfield (1959) using plasma from a case of severe congenital factor VII deficiency as substrate.

FACTOR VIII ASSAY By the kaolin clotting time method (Wolf, 1961) using plasma from a severe haemophiliac as substrate.
FACTOR X ASSAY By the method of Denson (1961) usingo commercially prepared factor $\mathrm{X}$ substrate plasma.

\section{DISCUSSION}

By adjustment of the infusion rate according to the results of the tests described, it is possible to을 maintain the necessary balance between an effective level of activator and overdosage. Although strepto- $\overrightarrow{-}$ kinase has been the activator in the present series, these tests can also be used for the control of $\vec{\omega}$ urokinase infusions.

The coagulation defect arising during thrombolytic therapy is due to the reduction of clotting factors by $\vec{v}$ proteolysis and the accumulation of the products of $\omega$ fibrinogenolysis which interfere with fibrin poly-i merization. There is some evidence that slow activation of plasminogen results in higher levels of free plasmin than if plasminogen depletion is brought about rapidly by a large initial dose of activator. Therefore the possibility of inducing a coagulation ${ }^{2}$ defect exists in both systemic and local therapy $\vec{\theta}$ although relatively smaller amounts of streptokinase + are infused in the latter. In our experience this defect is only significant if there is a lesion such as a recent operation wound or an area of cerebral softening.

Should it be necessary to reverse the systemic $\frac{}{\infty}$ effects of thrombolytic therapy the intravenous injection of epsilon-amino-caproic acid $^{1}$ will inhibit the action of streptokinase. The recommended dose of this drug which prevents the activation of plasminogen is $1 \mathrm{~g} . / 10 \mathrm{~kg}$. body weight (Nilsson and Olow, 1962b). The effects of the coagulation defect $\frac{8}{0}$ can then be controlled by infusion of fibrinogen and fresh frozen plasma or fresh blood.

We are most grateful to Kabi Pharmaceuticals for generous supplies of Kabikinase and epsilon-amino- $\frac{\text { O }}{2}$ caproic acid. We would also like to thank Dr. J. L. Stafford for his help with the preparation of this communication.

This work was supported by grants from the St. O George's Hospital Research Fund and the Medical N Research Council.

\section{REFERENCES}

Alkjaersig, N., Fletcher, A. P., and Sherry, S. (1959a). J. clin. Invest., 38, 1086.

- - - - (1959b). J. biol. Chem., 234, 832.

Biggs, R., and Macfarlane, R. G. (1962). Human Blood Coagulation and its Disorders, 3rd ed., p. 396. Blackwell, Oxford.

Buckell, M. (1958). J. clin. Path., 11, 403.

Denson, K. W. (1961). Acta haemat. (Basel), 25, 105.

'Epsilon-amino-caproic acid (Epsikapron) for intravenous injection is available as a $10 \%$ sterile solution from Kabi Pharmaceuticals Ltd. $?$ London. 
Dische, F. E., and Benfield, V. (1959). Ibid., 21, 257.

Fearnley, G. R., Balmforth, G., and Fearnley, E. (1957). Clin. Sci., 16,645 .

Fl etcher, A. P., Alkjaersig, N., and Sherry, S. (1959a). J. clin. Invest., 38, 1096.

- - (1959b). J. clin. Invest., 38, 1005. (Abst.)

Flute, P. T. (1960). Proc. 7th Congr. europ. Soc. Haemat., London, 1960, part 2, p. 894.

Hawkey, C. M., and Howell, M. B. (1964). J. clin. Path., 17, 363.

- , and Stafford, J. L. (1964). Ibid., 17, 175.

Howell, M. B. (1963). Ibid., 16, 289.

Johnson, A. J., and McCarty, W. R. (1959). J. clin. Invest., 38, 1627.
Niewiarowski, S., and Kowalski, E. (1958). Rev. Hémat., 13, 320.

Nilsson, I. M., and Olow, B. (1962a). Thrombos. Diathes. haemorrh. (Stuttg.), 8, 297.

,-- (1962b). Acta chir. scand., 123, 247.

Quick, A. J. (1957). Hemorrhagic Diseases, p. 379. Kimpton, London.

Ratnoff, O. D., and Menzie, C. (1951). J. Lab. clin. Med., 37, 316.

Remmert, L. F., and Cohen, P. P. (1949). J. biol. Chem., 181, 431.

Stefanini, M. (1951). Lancet, 1, 606.

Tillett, W. S., Johnson, A. J., and McCarty, W. R. (1955). J. clin Invest., 34, 169.

Wolf, P. (1953). J. clin. Path., 6, 34.

(1961). Personal communication.

\section{Broadsheets prepared by the Association of Clinical Pathologists}

The following broadsheets (new series) are published by the Association of Clinical Pathologists. They may be obtained from Dr. R. B. H. Tierney, Pathological Laboratory, Boutport Street, Barnstaple, N. Devon. The prices include postage, but airmail will be charged extra.

3 The Detection of Barbiturates in Blood, Cerebrospinal Fluid, Urine, and Stomach Contents. 1953. L. c. NICKOLLS. $1 \mathrm{~s}$.

4 The Estimation of Carbon Monoxide in Blood. 1953. D. A. STANLEY. 1s.

13 The Identification of Serotypes of Escherichia coli Associated with Infantile Gastro-enteritis. 1956. JOAN TAYLOR. $1 \mathrm{s.}$

16 Preservation of Pathological Museum Specimens. 1957. L. W. PROGER. 1s.

17 Cultural Diagnosis of Whooping-cough. 1957. B. W. LACEY. $1 \mathrm{~s}$.

20 Investigation of Porphyrin/Porphyria. 1958 (reprinted 1962). C. RIMINGTON. $2 s$.

23 The Dried Disc Technique for Bacterial Sensitivity Tests. 1959. R. W. FAIRBROTHER and J. C. SHERRIS. 1s.

24 Safe Handling of Radioactive Tissues in the Laboratory and Post-mortem Room. 1959. R. C. CURRAN. 1s.

26 The Periodic Acid-Schiff Reaction. 1959. A. G. E. PEARSE. 1s.

28 Daily Fatty Acid Excretion. 1960. A. C. FRAZER. 2 s.

29 The Preparation of Bone for Diagnostic Histology. 1960. D. H. COLLINS. 2s.

30 Control of Accuracy in Chemical Pathology. 1961. G. H. GRANT. $4 s$.

31 Investigation of Haemorrhagic States with Special Reference to Defects of Coagulation of the Blood. 1961. E. K. BLACKBURN. 4s.

32 Detection of Resistance to Streptomycin, P.A.S., and Isoniazid in Tubercle Bacilli. 1961. R. CRUICKSHANK and $S$. M. STEWART. 2 s.
33 The Laboratory Detection of Abnormal Haemoglobins. 1961. H. LEHMANN and J. A. M. AGER. 4s.

34 Titration of Antistreptolysin O. 1961. H. GOODER and R. E. O. WILLIAMS. $2 s$.

35 The Estimation of Faecal 'Urobilinogen'. 1961. C. H. GRAY. 2 s.

36 Quantitative Determination of Porphobilinogen and Porphyrins in Urine and Faeces. 1961. C. RIMINGTON. 3s. 6d.

37 The Paper Electrophoresis of Serum and Urinary Proteins. 1961. G. FRANGLEN and N. H. MARTIN. 4s.

38 The Augmented Histamine Gastric Function Test. 1961. M. LUBRAN. 2s.

39 Investigation of Haemolytic Anaemia. 1961. J. G. SELWYN. 2s.

40 Short-term Preservation of Bacterial Cultures. 1962. E. JOAN STOKES. $2 s$.

41 Serological Tests for Syphilis. 1962. A. E. WILKINson. 6s.

42 The Determination of Glucose 6-Phosphate Dehydrogenase in Red Cells. 1962. T. A. J. PRANKERD. 2s.

43 Mycological Techniques. 1962. R. W. RIDDELL. 3s. 6d.

44 The Laboratory Investigation of Catecholamine Secreting Tumours. 1963. M. SANDLER and C. R. J. RUTHVEN. 2s.

45 Diagnostic Test for Hereditary Galactosaemia. 1963. v. SCHWARZ. $2 \mathrm{~s}$.

46 The Determination of Serum Iron and Total Iron Binding Capacity. 1963. A. JORDAN and D. A. PODMORE. 2s. 